\title{
Intracranial Haemorrhage Associated with Hyaline Membrane Disease
}

\author{
V. C. HARRISON, H. de V. HEESE, and M. KLEIN \\ From the Neonatal Respiratory Unit, Department of Child Health, University of Cape Town, South Africa
}

Intracranial haemorrhage is commonly found at necropsy in association with hyaline membrane disease. The bleeding usually occurs in the subarachnoid or intraventricular sites (Hutchison, Kerr, Douglas, Inall, and Crosbie, 1964), but its cause is as yet poorly established.

Cerebral haemorrhage unrelated to hyaline membrane disease frequently occurs in premature infants (Craig, 1938), and anoxia is thought to be an important factor in its pathogenesis. The same sites are involved, but occasionally bleeding may present in the subdural space if blood under tension ruptures through the fine leptomeninges (Claireaux, 1964).

By contrast, traumatic bleeding from a torn falx cerebri or tentorium is subdural in origin and is most prevalent in full-term infants (Craig, 1938). The incidence of this complication has now declined, probably as a result of improved obstetrical management (Ahvenainen, 1964).

In the present study, a number of premature infants with hyaline membrane disease were found to have massive intracranial haemorrhage. All had suffered prolonged anoxia after birth, and were subsequently treated by artificial ventilation until death. Attention has been directed towards defining the role of anoxia, and in particular whether it is the cause of haemorrhage or whether it arises as a result thereof. The investigation has also been concerned with establishing whether the bleeding occurs as a chronic or an acute episode, and whether intermittent positive pressure respiration contributes in any way.

\section{Material}

Seventy infants presenting the features of hyaline membrane disease were admitted to a neonatal unit. All were premature by dates, their gestational ages ranging from 30 to 38 weeks, and their mean weight was $2 \cdot 19 \mathrm{~kg}$. They had presented a progressive course of dyspnoea from birth with the subsequent appearance

Received June 5, 1967. of grunting, rib recession, and cyanosis. Of the 70 , 8 were apnoeic and deeply cyanosed on admission, the only sign of life being an audible heart beat.

Generalized oedema was present in all infants, and each demonstrated the radiological picture of an air bronchogram and reticulogranular lung fields. Biochemical derangements included a respiratory and metabolic acidosis, with a mean $p \mathrm{H}$ of $7 \cdot 20, \mathrm{P}_{\mathrm{a}} \mathrm{CO}_{2}$ $58 \mathrm{~mm} . \mathrm{Hg}$, and base excess of $-7 \cdot 1 \mathrm{mEq} / 1 . \gamma$-globulins were reduced (Hardie, Heese, and Kench, 1965), with a mean value of $0.36 \mathrm{mg} . / 100 \mathrm{ml}$.

\section{Management}

The infants were nursed in incubators with a high environmental humidity and all received intravenous $10 \%$ glucose water $\left(50 \mathrm{ml} . / \mathrm{kg}\right.$. day). $4 \% \mathrm{NaHCO}_{3}$ was added to this fluid in amounts aimed to correct metabolic acidosis, as calculated from base excess readings. Oxygen was administered in high concentration to all babies, with the object of maintaining their arterial oxygen tensions between 70 to $100 \mathrm{~mm}$. Hg. $1 \mathrm{mg}$. vitamin $K_{1}$ was given intramuscularly. This therapy was instituted as soon as the diagnosis of hyaline membrane disease had been made, and in the majority of cases within the first few hours of life.

If the arterial oxygen tension could not be maintained above $50 \mathrm{~mm}$. $\mathrm{Hg}$, or if a single apnoeic episode with cyanosis occurred, the baby was intubated and treated by intermittent positive pressure respiration (IPPR) with $100 \%$ oxygen. This was administered by a Bird Mark 8 respirator, attached to an 'infant $Q$ circle'. The 8 babies who initially presented with severe apnoea required immediate IPPR, and despite intensive care a further 16 infants developed a single bout of apnoea during the acute phase of the disease, and underwent similar therapy. One further baby was persistently cyanosed with a low $\mathrm{P}_{\mathrm{a}} \mathrm{O}_{2}$, and received IPPR.

\section{Investigations}

Only the investigations carried out on infants receiving IPPR are presented in this study.

A polythene catheter was passed $8 \mathrm{~cm}$. up the umbilical artery and samples of blood were collected in heparinized glass tubes. $\mathrm{P}_{\mathrm{a}} \mathrm{CO}_{2}, p \mathrm{H}$, and base excess values were determined by the Astrup technique. A correction for temperature change was made where 
necessary (Rosenthal, 1948). $\quad \mathrm{P}_{\mathrm{a}} \mathrm{O}_{2}$ was determined by means of a Clark type micro-oxygen electrode.

Haemoglobin concentration was determined by the cyan-methaemoglobin method, using a Klett-Summerson photoelectric colorimeter. Deep rectal temperature was monitored continuously on a YSI model 43 Telethermometer.

In 8 cases, a polythene catheter was passed up the umbilical vein into the right atrium. It was attached to a P 23 De Statham strain gauge, and pressure changes were recorded on an Offner Dynograph. Oesophageal pressure changes were measured by means of a $6 \mathrm{~cm}$. long latex balloon fitted to a multiperforated catheter, which was connected to a PM 6 Statham pressure transducer. A fitting from the endotracheal tube to the same transducer was used to record mouth pressure. Flow rate was measured by means of a Fleisch 00 pneumotachograph, and electrically integrated into volume. In this manner lung compliance could be calculated from transpulmonary pressure and tidal volume.

\section{Results}

Twenty-five infants required IPPR for respiratory failure. They were divided into two groups of 9 and 16 infants according to the duration of anoxia which they had experienced. Discussion will be restricted to these 25 babies.

Group I: Severe prolonged anoxia. Nine infants suffered prolonged anoxia. One of these aged 7 days had a severe anoxic episode while on the respirator, and the other 8 had suffered severe anoxia before admission. At least three apnoeic attacks, associated with cyanosis and bradycardia (heart rate 20 to 60 per min.) had occurred in each of these infants, and all were apnoeic and cyanosed on admission. None had received adequate resuscitation or therapy for respiratory distress before admission.
All but one responded immediately to endotracheal intubation and IPPR. Their colour became pink, tone improved, and pulses became palpable. Neurological function at this stage, as assessed by their movements, Moro, and sucking reflexes, appeared normal. Acid-base balance, arterial $\mathrm{CO}_{2}$ and $\mathrm{O}_{2}$ tensions, as well as $\mathrm{Hb}$ levels were all normal at this time (Table I). Following resuscitation, however, the infants were unable to sustain spontaneous respiration without the assistance of IPPR.

Course. The further course of the remaining 7 infants was characterized in each case by a catastrophic collapse, developing over 15 minutes, which usually occurred on the second or third day following anoxia (Table II). The picture was that of shock, with pallor, cyanosis of mucous membranes, mottled skin, and impalpable pulses. Three babies presented abnormal neurological signs, with squinting, nystagmus, and jerking movements of the limbs. In all infants there was a drop in rectal temperature from a mean $36 \cdot 6^{\circ} \mathrm{C}$. to $33 \cdot 3^{\circ} \mathrm{C}$. At this stage one infant had been weaned off the respirator, but the others still required IPPR.

The time of collapse could not be predicted in any infant, but its appearance was associated with sudden changes in acid-base balance and blood gas tensions. These values had been determined within 5 hours preceding deterioration and were repeated within 30 minutes following the onset of shock. A severe metabolic acidosis occurred during this period, with a fall in the mean $p \mathrm{H}$ from 7.33 to 7.00 and a fall in base excess from $-6.5 \mathrm{mEq} / \mathrm{l}$. to $-17 \cdot 6 \mathrm{mEq} / \mathrm{l}$.

Arterial $\mathrm{O}_{2}$ tension fell from a mean $92 \mathrm{~mm} . \mathrm{Hg}$ before the event to $39 \mathrm{~mm}$. Hg (Table II). Artificial ventilation prevented any significant alteration in arterial $\mathrm{CO}_{2}$ tension, during the stage before the

TABLE I

Comparison of Two Groups of Apnoeic Infants During Artificial Ventilation

\begin{tabular}{|c|c|c|c|c|c|c|c|c|c|c|}
\hline & $\begin{array}{c}\text { Weight } \\
\text { (kg.) }\end{array}$ & $\begin{array}{c}\text { Gestation } \\
\text { (wk.) }\end{array}$ & $p \mathrm{H}$ & $\begin{array}{c}\text { Base } \\
\text { Excess } \\
(\mathrm{mEq} / \mathrm{l} .)\end{array}$ & $\underset{(\mathrm{mm} . \mathbf{H g})}{\mathbf{P}_{\mathrm{aCO}}}$ & $\begin{array}{c}\mathrm{P}_{\mathrm{a}} \mathrm{O}_{2} \\
(\mathrm{~mm} . \mathbf{H g})\end{array}$ & $\underset{(\mathrm{g} . / 100 \mathrm{ml} .)}{\mathrm{Hb}}$ & $\begin{array}{c}\text { Temp. } \\
\left({ }^{\circ} \mathrm{C} .\right)\end{array}$ & $\mid \begin{array}{c}\text { Compliance } \\
\left(\mathrm{cm} . \mathrm{H}_{2} \mathrm{O} /\right. \\
\mathrm{ml} .)\end{array}$ & $\begin{array}{c}\text { Mouth } \\
\text { Pressure } \\
\text { (cm. } \\
\mathrm{H}_{2} \mathrm{O} \text { ) }\end{array}$ \\
\hline $\begin{array}{cc}\text { Group I } & \\
\text { Mean } & \ldots \\
\text { SD } \pm & \ldots\end{array}$ & $\begin{array}{l}2 \cdot 16 \\
0 \cdot 68\end{array}$ & $\begin{array}{r}35 \cdot 0 \\
3 \cdot 4\end{array}$ & $\begin{array}{l}7 \cdot 32 \\
0 \cdot 08\end{array}$ & $\begin{array}{r}-5 \cdot 6 \\
2 \cdot 7\end{array}$ & $\begin{array}{l}37 \cdot 4 \\
10 \cdot 0\end{array}$ & $\begin{array}{l}99 \cdot 2 \\
10 \cdot 6\end{array}$ & $\begin{array}{r}18 \cdot 6 \\
2 \cdot 3\end{array}$ & $\begin{array}{r}36 \cdot 6 \\
0.8\end{array}$ & $\begin{array}{l}0.53 \\
0.07\end{array}$ & $\stackrel{33 \cdot 8}{-}$ \\
\hline $\begin{array}{c}\text { Group II } \\
\text { Mean } \\
\text { SD } \pm\end{array}$ & $\begin{array}{l}2 \cdot 12 \\
0 \cdot 37\end{array}$ & $\begin{array}{r}35 \cdot 3 \\
2 \cdot 1\end{array}$ & $\begin{array}{l}7 \cdot 36 \\
0 \cdot 10\end{array}$ & $\begin{array}{r}-2 \cdot 7 \\
2 \cdot 5\end{array}$ & $\begin{array}{r}40 \cdot 8 \\
8 \cdot 6\end{array}$ & $\begin{array}{l}83 \cdot 6 \\
23 \cdot 4\end{array}$ & $\begin{array}{r}16 \cdot 9 \\
1 \cdot 8\end{array}$ & $\begin{array}{r}36 \cdot 7 \\
0.9\end{array}$ & $\begin{array}{l}0 \cdot 56 \\
0 \cdot 10\end{array}$ & $\stackrel{33 \cdot 8}{-}$ \\
\hline$\underset{\text { Probability }}{\text { Deviation }}$ & $\begin{array}{r}1 \cdot 58 \\
>0 \cdot 80\end{array}$ & $\begin{array}{r}1.67 \\
>0.90\end{array}$ & $\begin{array}{r}0.50 \\
>0.50\end{array}$ & $\begin{array}{r}1 \cdot 58 \\
>0 \cdot 10\end{array}$ & $\begin{aligned} & 0.822 \\
> & 0.50\end{aligned}$ & $\begin{array}{ll} & 1 \cdot 673 \\
> & 0.10\end{array}$ & $\begin{aligned} & 1 \cdot 610 \\
> & 0 \cdot 10\end{aligned}$ & $\begin{aligned} & 0.116 \\
> & 0.90\end{aligned}$ & $\begin{aligned} & 0.482 \\
> & 0.60\end{aligned}$ & 二 \\
\hline
\end{tabular}

Group I: 8 infants who presented with prolonged apnoea and cyanosis.

Group II : 16 infants who developed a single episode of apnoea and cyanosis.

* No significant difference between the groups. 
TABLE II

Group I: Studies Before and After Intracranial Haemorrhage in Hyaline Membrane Disease

\begin{tabular}{|c|c|c|c|c|c|c|c|c|c|c|c|c|c|c|c|c|}
\hline \multirow{2}{*}{$\begin{array}{l}\text { Case } \\
\text { No. }\end{array}$} & \multirow{2}{*}{$\begin{array}{c}\text { Weight } \\
\text { (kg.) }\end{array}$} & \multicolumn{2}{|c|}{$\begin{array}{l}\text { Age } \\
\text { (hr.) }\end{array}$} & \multicolumn{2}{|c|}{$p H$} & \multicolumn{2}{|c|}{$\begin{array}{l}\mathrm{P}_{\mathrm{a}} \mathrm{CO}_{2} \\
\underset{\mathrm{Hg}}{\mathrm{mm}} .\end{array}$} & \multicolumn{2}{|c|}{$\begin{array}{c}\text { Base Excess } \\
(\mathrm{mEq} / 1 .)\end{array}$} & \multicolumn{2}{|c|}{$\underset{(\mathbf{m m} \cdot \mathbf{H g})}{\mathbf{P a O}_{\mathbf{2}}}$} & \multicolumn{2}{|c|}{$\underset{(\mathrm{g} . / 100 \mathrm{ml} .)}{\mathrm{Hb}}$} & \multicolumn{2}{|c|}{$\begin{array}{c}\text { Rectal } \\
\text { Temperature } \\
\left.{ }^{\circ} \mathrm{C} .\right)\end{array}$} & \multirow{2}{*}{$\begin{array}{c}\begin{array}{c}\text { Necropsy } \\
\text { Findings }\end{array} \\
\begin{array}{c}\text { Site of } \\
\text { Intracranial } \\
\text { Haemorrhage }\end{array}\end{array}$} \\
\hline & & a & b & a & b & $\mathbf{a}$ & b & a & b & a & b & $\mathbf{a}$ & b & a & b & \\
\hline $\begin{array}{l}1 \\
2 \\
3 \\
4 \\
5 \\
6 \\
7 \\
8 \\
9\end{array}$ & $\begin{array}{l}1 \cdot 53 \\
3 \cdot 63 \\
1 \cdot 70 \\
2 \cdot 18 \\
2 \cdot 85 \\
1 \cdot 70 \\
1 \cdot 87 \\
1 \cdot 84 \\
1 \cdot 21\end{array}$ & $\begin{array}{r}241 \\
50 \\
40 \\
67 \\
76 \\
43 \\
74 \\
49 \\
\end{array}$ & $\begin{array}{r}246 \\
54 \\
45 \\
72 \\
78 \\
49 \\
79 \\
54 \\
4\end{array}$ & $\begin{array}{l}7 \cdot 40 \\
7 \cdot 30 \\
7 \cdot 30 \\
7 \cdot 48 \\
7 \cdot 34 \\
7 \cdot 21 \\
7 \cdot 20 \\
7 \cdot 31 \\
-\end{array}$ & $\begin{array}{l}6 \cdot 99 \\
7 \cdot 03 \\
7 \cdot 01 \\
7 \cdot 01 \\
6 \cdot 99 \\
7 \cdot 19 \\
7 \cdot 01 \\
7 \cdot 27 \\
6 \cdot 82\end{array}$ & $\begin{array}{l}44 \\
43 \\
33 \\
23 \\
33 \\
58 \\
34 \\
32 \\
\end{array}$ & $\begin{array}{l}42 \\
68 \\
33 \\
45 \\
35 \\
50 \\
40 \\
33 \\
31\end{array}$ & $\begin{array}{r}0 \\
-5 \\
-9 \\
-5 \\
-7 \\
-5 \\
-15 \\
-9 \\
-\end{array}$ & $\begin{array}{l}-20 \\
-12 \cdot 9 \\
-19 \\
-18 \\
-21 \\
-9 \\
-19 \\
-11 \cdot 5 \\
-22\end{array}$ & $\begin{array}{r}155 \\
88 \\
115 \\
68 \\
85 \\
84 \\
54 \\
145\end{array}$ & $\begin{array}{l}30 \\
45 \\
42 \\
40 \\
37 \\
30 \\
56 \\
52\end{array}$ & $\begin{array}{l}19 \\
21 \cdot 1 \\
16 \\
19 \\
20 \\
17 \\
22 \\
15\end{array}$ & $\begin{array}{l}14 \\
18 \\
11 \\
15 \\
10 \\
9 \cdot 5 \\
17 \\
12 \cdot 5 \\
12\end{array}$ & $\begin{array}{l}36 \cdot 6 \\
36 \cdot 3 \\
36 \cdot 2 \\
36 \cdot 1 \\
36 \cdot 1 \\
36 \cdot 1 \\
37 \cdot 2 \\
36 \cdot 2 \\
-\end{array}$ & $\begin{array}{l}32 \cdot 7 \\
32 \cdot 2 \\
33 \cdot 8 \\
33 \cdot 3 \\
32 \cdot 7 \\
36 \cdot 1 \\
32 \cdot 7 \\
32 \cdot 2\end{array}$ & $\begin{array}{l}\text { Intraventricular } \\
\text { Subarachnoid } \\
\text { Intraventricular } \\
\text { Subarachnoid } \\
\text { Intraventricular } \\
\text { Intraventricular } \\
\text { Subarachnoid } \\
\text { Intraventricular } \\
\text { Intraventricular }\end{array}$ \\
\hline Mean & $2 \cdot 12$ & - & - & $7 \cdot 33$ & $7 \cdot 00$ & 38 & 43 & $-6 \cdot 5$ & $-17 \cdot 6$ & 92 & 39 & $18 \cdot 6$ & $12 \cdot 5$ & $36 \cdot 6$ & $33 \cdot 3$ & \\
\hline
\end{tabular}

(a) Investigations within five hours preceding the onset of shock.

(b) The same investigations within 15 minutes following shock.

appearance of shock, mean $\mathrm{P}_{\mathrm{a}} \mathrm{CO}_{2}$ being $38 \mathrm{~mm}$. $\mathrm{Hg}$, and afterwards $43 \mathrm{~mm}$. $\mathrm{Hg}$. In the infant who had been weaned off the respirator (Case 2, Table II), however, the $\mathrm{P}_{\mathrm{a}} \mathrm{CO}_{2}$ rose to $68 \mathrm{~mm}$. $\mathrm{Hg}$.

The $\mathrm{Hb}$ concentrations had been determined within 8 hours preceding collapse. They were repeated within 30 minutes after the event. In all infants a marked drop in concentration occurred; the mean value for the group before and after deterioration was $18 \cdot 6$ and $12 \cdot 5 \mathrm{~g} . / 100 \mathrm{ml}$. (Table II).

Outcome. All infants died within a few hours of developing shock despite IPPR and the administration of intravenous $\mathrm{NaHCO}_{3}$ or THAM. These substances, however, were ineffective in repairing the severe metabolic acidosis.

At necropsy all infants revealed massive intracranial haemorrhage in association with hyaline membrane disease. In 4 cases bleeding was confined to the intraventricular region and in 3 to the subarachnoid space. No evidence of cerebral trauma could be detected and the airways were patent.

Of the 9 infants in Group I, 2 presented in a somewhat different manner. One (Case 9, Table II), who had been moribund at the time of admission, could not be revived by IPPR. Hb concentration and arterial $\mathrm{O}_{2}$ tension were low and a gross metabolic acidosis persisted despite the measures described to combat it. The baby died in this shock-like state 2 hours after admission, at the age of 6 hours. Necropsy revealed a large intraventricular haemorrhage. The lungs had the features of hyaline membrane disease. The second infant (Case 1, Table II) had been treated with high concentrations of oxygen and intravenous alkali and glucose since shortly after birth. On the third day a tension pneumothorax developed which was drained. Thereafter, respiration was impaired and the infant remained cyanosed, with $\mathrm{P}_{\mathrm{a}} \mathrm{O}_{2}$ $44 \mathrm{~mm}$. Hg. IPPR was therefore started. On the seventh day, obstruction of the endotracheal tube resulted in a prolonged bout of anoxia, lasting approximately 12 minutes. Immediate improvement followed a tube change and the baby appeared normal, but 2 days later, while still receiving IPPR, a catastrophic collapse occurred, with the appearance of metabolic acidosis, hypoxaemia, and anaemia. The baby died some hours later and was found to have a large intraventricular haemorrhage. The lungs showed features of resolving hyaline membrane disease.

Group II: Single short episode of anoxia. Sixteen infants were included in this group. From the early stages of the disease all had been treated with humidified oxygen, intravenous glucose, and sodium bicarbonate. Despite these measures, they developed apnoea at ages ranging from 4 to 36 hours. A single apnoeic spell with cyanosis, hypotonia, and marked slowing of the heart occurred in each infant. Apnoea lasted from 3 to 7 minutes before IPPR was instituted. A marked improvement followed this therapy, but these infants, like those in Group I, were unable to maintain adequate ventilation without the continuation of IPPR.

Course. Their subsequent course, however, was distinctly different and no sudden collapse occurred at any stage. Three infants contracted a superimposed bronchopneumonia and their lungs became progressively more difficult to ventilate. Initially, the low $\mathrm{P}_{\mathrm{a}} \mathrm{O}_{2}$ and raised $\mathrm{P}_{\mathrm{a}} \mathrm{CO}_{2}$ could be corrected by increasing the pump pressure, but over a number of days a stage was reached where correction became 
impossible and the babies died. Post mortem there was no intracranial haemorrhage. The remaining 13 infants were weaned off respirator therapy and recovered, though 2 of them died subsequently of specific Esch. coli 0.111 gastroenteritis at the age of 2 months. The morbid anatomical and histological appearance of the brain was normal in each case. The neurological development of the other 12 infants has subsequently been assessed as normal, at ages ranging from 5 to 18 months.

Comparison of Groups I and II. The infants of each group were compared in regard to their weights and maturity (Table I). Following the institution of IPPR no features appeared which distinguished the one group from the other. The clinical and biochemical aspects were similar, and there was no way of predicting when an infant would suddenly collapse and die. Lung function was grossly impaired in each group and the infants required high pump pressure to maintain the $\mathrm{P}_{\mathrm{a}} \mathrm{CO}_{2}$ at normal levels. Lung compliance was reduced to mean values of 0.56 and $0.53 \mathrm{~cm} . \mathrm{H}_{2} \mathrm{O} / \mathrm{ml}$. in each group, while the mean peak mouth pressure was $33.8 \mathrm{~cm} . \mathrm{H}_{2} \mathrm{O}$. Only $8 \%$ of this pressure was transmitted across the lungs to the veins, the mean right ventricular pressure being $2.9 \mathrm{~cm}$. $\mathrm{H}_{2} \mathrm{O}$.

\section{Discussion}

This study contrasts two groups of infants who required artificial ventilation because of anoxia. Babies who had suffered a single short spell of apnoea could readily be resuscitated by IPPR, and in the majority of cases recovered without complication. On the other hand, infants who had experienced prolonged episodes of anoxia could initially be revived by IPPR, but died later following the sudden onset of shock.

It is considered that prolonged or recurrent attacks of anoxia constitute the underlying factor in intracranial haemorrhage associated with hyaline membrane disease. It may be argued that early inability to breathe is due to underlying cerebral haemorrhage which begins at or before birth. However, the phase of recovery following IPPR points to a delay in the onset of bleeding. During this period the infants in our study could not be distinguished in any way from those who required IPPR for a single episode of apnoea with cyanosis. It was impossible to predict at this stage which infants would develop intracranial haemorrhage.

The initial apnoea in both groups was most probably precipitated by the inability of the infants to achieve adequate ventilation. The degree of impaired lung function could be assessed from the high pump pressure required to maintain the $\mathrm{P}_{\mathrm{a}} \mathrm{CO}_{2}$ within normal limits, and the much reduced lung compliance. Continued dependence on artificial ventilation was again determined by the state of the lungs, as at this stage factors which could produce cerebral depression, such as anoxia, hypercapnia, and hypoglycaemia, had been corrected.

Intracranial bleeding occurs as a catastrophic event, rather than as a slow leak. This is supported by the fact that the collapsed state observed in the infants was of sudden onset and had the features of acute blood loss, with anaemia, cyanosis, and impalpable pulses. Hb concentration, which up to this stage had been normal, dropped precipitously. Both metabolic acidosis (Simeone, 1965) and a decreased oxygen transport capacity of the blood (Cournand, 1963) are known to occur in hypovolaemic states due to haemorrhage. Stahlman, Battersby, Shepard, and Blankenship (1967) described intracranial haemorrhage occurring in 13 of 26 cases which died of hyaline membrane disease: the complication presented as a catastrophic event late in the course of the disease.

The factors responsible for the delay in bleeding are unknown. It is conceivable that tissue becomes necrotic and ruptures at a later stage. The interval between anoxia and haemorrhage was usually 2 days, but in one infant bleeding was present at 4 hours of age, and factors other than tissue necrosis may have precipitated intracranial haemorrhage in this case. The role of contributory factors such as hypoprothrombinaemia and hypofibrinogenaemia were not assessed in this study, but no infant revealed clinical evidence of a haemorrhagic tendency.

The investigation does not support the view (Tizard, 1964; Strang and MacLeish, 1961) that hypercapnia plays an important role in the causation of cerebral haemorrhage. The complication occurred in the presence of a normal or near normal $\mathrm{P}_{\mathrm{a}} \mathrm{CO}_{2}$. Presumably hypercapnia was present only early in the disease, during the period of ventilatory failure.

All infants died while receiving IPPR; it, therefore, remains to consider this form of therapy as a causative factor. No radiological evidence of a pneumothorax was present at the time of collapse. Despite high pump pressures which were delivered to the lungs, very little of this pressure was transmitted to the veins, because of the abnormally solid pulmonary tissue. It thus appears improbable that IPPR influences the onset of intracranial bleeding, particularly as infants who did not experience prolonged anoxia recovered without this complication. 


\section{Summary}

Prolonged anoxia is the major factor responsible for intracranial haemorrhage associated with hyaline membrane disease. Bleeding is confined to the intraventricular and subarachnoid regions, and occurs as a catastrophic event, usually two to three days after the anoxic episode. This pattern was observed in 9 infants who required artificial ventilation for repeated apnoeic attacks. These babies would probably have died of respiratory failure had they not received positive pressure ventilation. This form of therapy, rather than causing the complication, permitted the study of its course.

A short spell of anoxia, on the other hand, does not carry the same ominous implication and may be treated by means of artificial ventilation without fear of intracranial haemorrhage during the course of the disease.

Thanks are due to Dr. J. G. Burger, Medical Superintendent of Groote Schuur Hospital, for permission to publish, to Professor F. J. Ford for facilities and advice, to Professor J. G. Thomson for necropsy studies, to Mrs. O. M. Cartwright and Miss M. Hirschmann for their help in the preparation of the manuscript, to
Sister A. Goble for her expert infant care, and to the Wellcome Trust for financial assistance.

\section{REFERENCES}

Ahvenainen, E. K. (1964). Intracranial hemorrhages in premature infants. Ann. Paediat. Fenn., 10, 71.

Claireaux, A. (1964). Intracranial haemorrhage in the premature infant. Develop. Med. Child Neurol., 6, 518.

Cournand, A. (1963). Hémodynamique et échanges respiratoires dans le choc. Proc. VIIth int. Congr. int. Med., 1, 366

Craig, W. S. (1938). Intracranial haemorrhage in the new-born. Arch. Dis. Childh., 13, 89.

Hardie, G., Heese, H. de V., and Kench, J. E. (1965). Serumproteins in the idiopathic respiratory-distress syndrome of the newborn. Lancet, $2,876$.

Hutchison, J. H., Kerr, M. M., Douglas, T. A., Inall, J. A., and Crosbie, J. C. (1964). A therapeutic approach in 100 cases of the respiratory distress syndrome of the newborn infant. Pediatrics, 33, 956.

Rosenthal, T. B. (1948). The effect of temperature on the $\mathrm{pH}$ of blood and plasma in vitro. $\mathcal{F}$. biol. Chem., 173, 25.

Simeone, F. (1965). Experimental hemorrhagic shock and irreversibility. In Shock and Hypotension, ed. L. C. Mills and J. H. Moyer, p. 588. Grune and Stratton, New York.

Stahlman, M. T., Battersby, E. J., Shepard, F. M., and Blankenship, W. J. (1967). Prognosis in hyaline-membrane disease: use of a linear-discriminant. New Engl. F. Med., 276, 303.

Strang, L. B., and MacLeish, M. H. (1961). Ventilatory failure and right-to-left shunt in newborn infants with respiratory distress. Pediatrics, 28, 17.

Tizard, J. P. M. (1964). Indications for oxygen therapy in the newborn. ibid., 34, 771 . 